\title{
8. Towards a History of the Australian Accent
}

\section{Bruce Moore}

In 1927 in Australian Pronunciation: A Handbook for the Teaching of English in Australia, Ruby W. Board presents a firm notion of what the best pronunciation of English is:

In every English-speaking country there is to be found amongst cultivated people a certain pronunciation, which is unconsciously accepted as the best speech. On examination no trace of dialect can be detected, nothing that will single out the speaker, no touch of provincialism or of affectation. It is understood by all without effort, it is pleasant to the ear, and it may be heard in England, Scotland, Ireland, in all of the British Dominions, and even occasionally in America. It is significant that while the particularly obtrusive quality of the Oxford man, the Cockney, the Yorkshireman, the Scotchman, the Australian, the Canadian, is noted and labelled, the speech referred to above is described as good English. ${ }^{1}$

The swipe at Americans and American speech demonstrates the extent to which this cultivated pronunciation (or 'received pronunciation', as it had been called by A. J. Ellis in 1869) ${ }^{2}$ is a product of empire. Its endorsement as 'the best speech' at this point in Australia's history is entirely in keeping with the dying out of the radical nationalist movement in the 1890s, and the development of the curious blend of Australianness and Britishness that framed notions of nationalism in twentieth-century Australia. As Ben Wellings argues: 'Much of the content of Australian nationalism was derived from Britishness and adapted to local conditions, resulting in national consciousness as much merged with imperial symbols, as developed from the vernacular culture of the Australian people.' ${ }^{3}$ Another educationalist, Ethel M. Mallarky, writing in 1914, attempts to have it both ways when, on the one hand, she accepts the fact that Australian English has diverged from 'accepted standards of speech' ('It is to be expected - and need we strive to hinder it? - that a distinctive Australian speech will emerge with the Australian people's emergence into nationhood'), but goes on to insist that standards of empire pronunciation must be maintained:

But there are certain grave dangers by which the English tongue is being assaulted in Australia, peculiarities which may seriously militate against its efficiency as an instrument for the communication of thought. And further, as habit of speech tends to mark social boundaries, so in a wider 
degree, and far more distinctly, may it operate to demarcate national boundaries and lead to a weakening of that common sentiment which maintains healthy life in the Empire, and serves to keep in sympathetic relations all the widely scattered units of the English-speaking race. ${ }^{4}$

In this environment, it is not surprising that about this time the Australian accent became a target for quite widespread criticism. Valerie Desmond in The Awful Australian (1911) writes:

In conclusion, it is only necessary to point out that so objectionable is the Australian accent that theatrical managers resolutely refuse to employ Australian-born actors and actresses. Though a few of these are possessed of talent - or what passes for talent in Australia - the managers prefer to import English artists of inferior merit, solely because they possess the essential qualifications that Australians lack - the ability to speak the English language. ${ }^{5}$

In the same year, William Churchill writes: 'The fact remains that the common speech of the Commonwealth of Australia represents the most brutal maltreatment which has ever been inflicted upon the language that is the mother tongue of the great English nations.' 6

In 1926, a former Director of Education in New South Wales bemoans the accent: 'If we must follow a dialect of English in Australia, why not follow one of the charming ones? Why follow the ugliest that exists? ${ }^{7}$

In the nineteenth century, there were some occasional early comments on the Australian accent that were critical, or that might be taken as critical. First, there is Peter Cunningham, who, in Two Years in New South Wales (1827), claims that 'the London mode of pronunciation has been duly ingrafted on the colloquial dialect of our Currency youths, and even the better sort of them are apt to meet your observation of "A fine day", with their improving response of "Wery fine indeed!"'.8 There is, however, no other supporting evidence for Cunningham's claim of Cockney influence, and it is not until the end of the century that the Cockney shibboleth appears again - at a time when there is no longer a possibility of influence.

Secondly, there are writers who comment on intonation and articulation. Mrs Charles Meredith, in Notes and Sketches of New South Wales During a Residence in the Colony from 1839 to 1844 (1844), claims that 'a very large proportion of both male and female natives snuffle dreadfully; just the same nasal twang as many Americans have'. 9 Nasality is commented on by R. H. Horne in Australian Facts and Prospects (1859), ${ }^{10}$ and by a number of writers in the 1890s. Rolf Boldrewood in Robbery Under Arms (1882-83) says that in contrast with the Americans, 'most of the natives have a sort of slow, sleepy way of talking'. ${ }^{11}$ The Australian-born Rosa Praed also notes the elision of consonants in The 
Romance of a Station: An Australian Story (1889) in the speech of the stockman Tillidge: 'He pulled up, nodding to Alec's "Good-day, Tillidge," and replying in a short, morose manner, running his words one into the other, as a bushman does, "G'd-day, sir"". 12 In Outlaw and Lawmaker (1893), Praed notes a drawl in Australian speech: 'Lady Horace came slowly down the log steps, and held out her hand to Hallett. "How do you do," she said, in her gentle little Australian drawl. ${ }^{\prime 13}$

Interestingly, these features - nasality, a flatness arising from a lack of variation in intonation, a drawl, elision of syllables - became the stereotypes of Australian English in the first half of the twentieth century, ${ }^{14}$ but from the evidence we have they were hardly of great concern in the nineteenth century. Indeed, the typical descriptions of the Australian accent for most of the nineteenth century are not critical, and do not focus on what might be potentially negative aspects of the accent; they are overwhelmingly positive. James Dixon, in Narrative of a Voyage to New South Wales and Van Dieman's Land in the Ship 'Skelton' during the year 1820 (1822), writes: 'The children born in those colonies, and now grown up, speak a better language, purer, more harmonious than is generally the case in most parts of England. The amalgamation of such various dialects assembled together, seems to improve the mode of articulating the words.' ${ }^{15}$

Especially in the light of recent research on the development of colonial English, this is the most significant observation on Australian English in the nineteenth century. New Zealand researchers ${ }^{16}$ have shown-from an examination of recordings of New Zealand speakers who were born to the first generation of settlers in New Zealand - that the children of this first generation did not reproduce the accents of their parents, and did not develop a single accent under peer-group pressure. Rather, each child picked up different features of accent from the varying dialects surrounding them. It is in the following generation that the 'foundation accent' is established, when all of the children speak with much the same accent. Due to the special circumstances of NSW being a penal colony, it is not possible simply to transport the New Zealand pattern to Australia, but whether Dixon was listening to first-generation or second-generation children, the significant fact is that he notes that their speech is not heavily marked for dialect, and that he says their speech is purer than that spoken by children in most parts of England. By 'pure' Dixon does not mean that the speech approaches an ideal; rather, he means that the speech is not marked heavily for dialect. All of this is entirely in keeping with what we now know about the development of a local variety of English in a colonial society.

Much the same point as Dixon's was made by George Bennett a decade later in Wanderings in New South Wales, Batavia, Pedir Coast Singapore, and China (1834):

It has often been mentioned by writers upon the United States of America, that a purer and more correct English is spoken in that country than in 
the 'old country' where it is corrupted by so many different provincial dialects. The remark respecting the United States of America will equally apply to Australia; for among the native-born Australians (descended from European parents), the English spoken is very pure; and it is easy to recognise a person from home or one born in the colony, no matter what class of society, from this circumstance. ${ }^{17}$

The word 'purer' appears again, and again the observer notes the absence of strong dialectal features in the speech of the native-born. Across all classes, the native-born all speak with the same accent - the foundation accent has been established. Because it is the foundation accent it will not be possible for other accents - which will continue to be transported to Australia - to have any significant effect on this foundation accent.

Caroline Leakey's The Broad Arrow was published in 1859, but it relates to the years 1848-53 when the Exeter-born Leakey spent five years in Tasmania with her sister. She makes some interesting observations on the language of the Tasmanian-born when describing Hobart:

The incongruous medley of shops, rich and poor together, is London-like. Butcher, baker, grocer, all appear to have served their apprenticeship in the capital; the cut of the meat, the shape of the bread, the adulteration of the groceries, are in dutiful or unintended remembrance of Cockney education.

Are all the tradespeople of London origin that it should be so, uncle?

By no means. Trades from every part of Britain have settled here. Every county has its representative, every provincial custom its follower. Every grade and every phase of English life meet out here. It is probably this very amalgamation that reproduces the English metropolis.

To the same cause may be attributed the freedom from peculiarity in the tone and pronunciation of the natives. As children they have no opportunity to contract the nasal twang or gutturals of any particular province; by the constant change of servants, and from an intercourse with a diversity of accents, they are preserved from fixing on any one peculiarity. The Irish brogue heard today is to-morrow changed for the broad Scotch accent; the Devonshire drawl soon forgotten in the London affectation; the Somersetshire z's are lost in Yorkshire oo's. If you have not already remarked it, you cannot fail shortly to note how very well the common children speak, even where the parents set them no good pronunciative example. ${ }^{18}$

This passage provides further evidence that the Australian accent developed from a process of the levelling and excision of obvious dialectal features. Leakey was obviously familiar with the social and business milieu of the London 
Cockneys, and although she noted their influence on the worlds of butcher, baker and grocer, she heard nothing in the speech of the native-born Australians to remind her of Cockney speech. She says they speak 'well', clearly a synonym for the 'pure' of Dixon and Bennett.

Finally, in 1886, James Froude in Oceana, or, England and her colonies comments: 'The first thing that struck me - and the impression remained during all my stay in Australia - was the pure English that was spoken there. ${ }^{19}$

How, then, can we explain these different evaluations of the Australian accent? Until the mid-1880s, the accent of native-born Australians was regarded as pure, and it was praised for being free of any elements of British dialects. In the first half of the twentieth century, it was regarded as impure, ugly and substandard. It is simply not credible to suggest that the accent changed in one generation. The only explanation possible is that something caused a change in attitude towards the Australian accent.

We are fortunate in having evidence that demonstrates this change of attitude taking place. From the mid-nineteenth century, school inspectors in the various colonies (and later, states) reported annually to parliament on the standards of school students. The typical report dealt with such aspects as reading, writing, composition, spelling, arithmetic, grammar and geography. One very early report from 1855 makes a comment that is potentially in keeping with the twentieth-century comments: 'Little care is apparently taken to correct vicious pronunciation or improper modulations of voice, and we often had occasion to remark, while hearing the children read, that this inattention has a tendency to foster an Australian dialect which bids fair to surpass the American in disagreeableness. ${ }^{20}$ This is not, however, typical, and most of the comments for the next three decades are about non-standard features such as h-dropping, and general observations about carelessness in language use.

Here are some typical comments: from 1863, 'The commoner defects in the articulation are the drawling out of one or more of the vowel sounds, and the substitution of $\mathrm{r}$ for that of the terminational $\mathrm{w}^{\prime} ;^{21}$ from $1875-76$, 'The omission of the letter $h$ (even in the reading of the pupil-teachers) is the chief defect' ${ }^{22}$ from 1876-77, 'The chief faults of pronunciation against which a constant struggle has to be carried on are the misplacing of the letter $h$, the omitting to sound $s$ at the end of a word, and the withholding its proper force from the final $-i n g^{\prime} .23$

From 1879-80:

There are some words that one hears mispronounced in the schools more frequently than others. For example, many children append in pronunciation a $t$ to these words: cliff, once, sudden; misplace the accent 
in distribute, executive, laborious, mischievous; and give the wrong sound to the last syllable in massacre. ${ }^{24}$

From 1884-85:

The children drop their h's without correction, and in some cases the teachers set them the example. From the Cockney and Cornish the disease has spread to the Scotch and Irish. We are in a fair way of becoming a nation without an $\mathrm{h}$ in our vocabulary...There are other weak points in Victorian pronunciation; but this, I think, is the worst. ${ }^{25}$

From 1886: 'The most common defects are...disregard of the aspirate, and a corruption of ing into en, as written, readen for writing, reading. ${ }^{26}$

The one exception to this early emphasis on non-standard features is an early concern with the pronunciation of the diphthong heard in the word 'cow'. An 1861 report from NSW comments briefly on the pronunciation caow for cow, ${ }^{27}$ and an 1869 Tasmanian report similarly comments on 'cow': one of the two gravest defects in the pronunciation of young Tasmanians...[is] the drawling of the diphthongs ou and ow, as in "maountain" for "mountain", "taown" for "town", and so on'. ${ }^{28}$ But such comments are not typical of the early period, and no further comments on the quality of vowels and diphthongs appear until the mid-1880s, with the heaviest emphasis being in the 1890s and the first decade of the twentieth century. In this later period, the sounds commented on most commonly are the diphthongs that occur in 'take', 'hide', 'cow' and 'go', and the vowels that occur in 'hat' and 'get'. A report from 1891-92 comments on 'take', claiming that 'tail' is often pronounced as 'tile'. ${ }^{29}$ A Victorian report from 1891-92 comments on 'hide', claiming that 'miners' is often pronounced as 'moiners'. 30

The early comments on 'cow' in NSW and Tasmania have been noted; an 1891-92 Victorian report takes this up: 'The mispronunciation of...the diphthong "ow", as in brown...is frequently allowed to pass uncorrected. Thus a child might read- "The 'breown' bear".'31 An 1893-94 report comments on 'go': 'The vowel sounds suffer badly in our schools...go becomes gao.' 32 A report from 1893 focuses on 'hat': 'The short $a$ is sometimes pronounced like e, e.g., ketch for catch.' ${ }^{33}$ An 1885-86 report comments on 'get', claiming that 'Ben' appears as 'Bin'. ${ }^{34}$ These are among the most important sounds that distinguish the Australian accent from other English accents.

For the purposes of this essay, I will focus on the sound in 'take'. This sound is the difference most commonly perceived between Australian English and received pronunciation and other Englishes, and is regarded as the most distinctive of the Australian sounds. The Australian English realisation of the diphthong often results in non-Australian speakers perceiving the sound as closer to 'mike' than 'make'. 
Comments on this sound in the school inspectors' reports from the period 1886 to 1914 include: from 1885-86, 'The following errors, I have noticed, are very prevalent...vowel mispronunciation - , ai, ay $=\overline{1}+$ (very short); e.g., late $=$ lì't, rain, day, etc. ${ }^{35}$ From 1891-92: 'The mispronunciation of some of the vowel sounds (especially...the long "a", as in tail...is, however, still very common, and is frequently allowed to pass uncorrected. Thus a child might read- "The [brown] bear has a very short 'tile"' ... and such pronunciation be unnoticed.' 36

From 1893: 'The long $a$ is often made into a diphthong: I have a lively recollection of hearing the song "Our Jack's Come Home To-day" cheerfully rendered "Our Jack's Come Home to Die!"'37 From 1893-94: 'I have reluctantly to confess that the vowel sounds suffer badly in our schools - that page becomes pahidge.' 38 From 1899-1900: 'The long a sound is too frequently given very much like the long $i$ sound, and I am frequently reminded of the lady's invitation to take some cake in preference to grapes - "Tike some kike, I mide it myself; you can have the gripes after". 39

Also from 1899-1900: "The sound of " $a$ ", as in fate, is frequently heard both in the reading and oral answers of the children as a diphthong closely approximating to the sound of " $\mathrm{i}$ " in mind. It is somewhat startling to be told that Limerick is noted for the manufacture of lice (lace). ${ }^{40}$

From 1902-03:

It is hard to show them the difference between sail and sile (nearly), kaite and kite...The long ' $a$ ' is the vowel which suffers the greatest distortion. 'Later', heard apart from any context, would be easily mistaken for 'lighter', and 'rain', sounded under like circumstances, is hardly distinguishable from 'Rhine'...Playgoers are familiar with the cry of the itinerant vendors of refreshment between the acts. 'Apples, gripes (grapes), lemonide (lemonade). ${ }^{41}$

From 1903-04:

With the vowels, the ah sound, which is the first attacked in teaching deaf mutes to read and speak, is the easiest of all; it necessitates the least exertion of the organs of speech, and on this account the children attempt to form all the vowel sounds with the lips, tongue, throat, \&c., in position to make this sound. Hence sah-eel (sile nearly) for sail. ${ }^{42}$

From 1906-07: The vowel sounds are well attended to. Sy for say, soide for side...are not frequently heard; but they do still occur, and require constant attention.' 43 From 1908-09: "The making of the long "a" sound into " $i$ " [is] still rather common in many schools. ${ }^{44}$ From 1910: "A few vulgarisms of pronunciation not infrequently assail one's ears, such, for instance, as..."pide" for "paid".' 45 
From 1911-12: 'I am glad to say that the vowel sounds, which were rather bad at first, are receiving much attention. The "da-owns" and "ta-owns", and "si-lings daown the by", and "moindings" of the "boikes" are slowly disappearing. ${ }^{46}$

At the same time as the school inspectors and the writers in the educational journals were commenting on the transformation of 'make' into 'mike', other commentators joined the chorus. In 1887, the Scottish-born Victorian schoolteacher Samuel McBurney collected material on pronunciation in Australia and New Zealand for A. J. Ellis's Early English Text Society books on the pronunciation of English. McBurney believed that some of the distinctive Australian sounds were the same as corresponding sounds in Cockney, although he did not argue that Cockney influenced Australian, and he seemed to use 'Cockney' as a blanket term for 'non-standard'. It is interesting that among the features he notes as being shared by Cockney and Australian are precisely those that appear in the reports of the school inspectors, especially the diphthong in 'take' ('alteration of $a$ in fate, to nearly $i$ in bite'), 'cow' ('alteration of the first factor of ow in cow, so that it is written kyow, or caow') and 'go' ('alteration of $o$ in hope, to nearly ow in how'). ${ }^{47}$ The distinctive 'take' diphthong was also noted in 1892 by visiting British writer G. L. James:

As to the English spoken in Australia, I believe it has already been remarked how correct, as a rule, it is, and I think it is free from any distinguishing accent or provincialism to a marvellous extent, while the tone of voice is pleasing and well modulated. In Sydney, however, more particularly the young girls, especially of the lower classes, are apt to affect a twang in pronouncing the letter $a$ as if it were $i$, or rather $a i$ diphthong.

Thus, the refrain to a well-known song will be pronounced as follows:-

Is this a dream?

Then wiking would be pine.

Oh! do not wike me,

Let me dream agine. ${ }^{48}$

In December 1893, the Chief Justice of Victoria, Sir John Madden, at the speech day of the Methodist Ladies' College in Melbourne, made a number of comments on Australian English. He exhorted young Australians to 'pronounce the English vowels as they were intended', and berated them for mangling their diphthongs: "The average Australian youth turns a into i, and o into aow or eow. He says "dy" instead of "day", "keow" instead of "cow", and "heow" instead of "how".,49

Thus in the late 1880s, and especially in the 1890s and the first decade of the twentieth century, there developed a prescriptivist attitude towards Australian vowels and diphthongs - they were being judged against an 'ideal' or 'standard' 
pronunciation, and the way Australian English diverged from that was noted increasingly.

Where does this standard come from? There has been much debate about the development of received pronunciation. In the comments on accent in Britain in the eighteenth and nineteenth centuries, it is often difficult to know if the writer is simply recommending the excision of dialectal sounds, or is urging a move towards a commonly accepted, or 'received', ideal. The earlier comments, however, seem concerned largely with excision. Thus in the eighteenth century, when Mrs Elizabeth Montague asserts that provincial accents are not acceptable 'in this polished age' and avers that the 'Kentish dialect is abominable, though not as bad as the Northumberland and some others', 50 there is no suggestion that she has an armoury of ideal vowels and diphthongs to fight off the barbarians.

Lynda Mugglestone has demonstrated that by the end of the eighteenth century there was developing a concept of standard speech, indicated by books such as John Walker's Critical Pronouncing Dictionary of 1791. ${ }^{51}$ As Honey has shown, however, the widespread dissemination of the standard that was to become received pronunciation was a post-1850 phenomenon, based initially in the public school system. ${ }^{52}$ Australian educators became aware of this new standard of correctness, and the comments of the school inspectors and the writers of the educational journals reflected increasingly the growing awareness that Australian vowels and diphthongs differed from this new standard.

Another interesting feature of the Australian school inspectors' reports and the educational journals that start to note 'faulty' vowel sounds is that they reveal a developing interest in elocution in Australia. ${ }^{53}$ There is much discussion in the inspectors' reports and in the educational journals of elocution books, elocution teachers and of the need for teachers to retrain in the principles of elocution. Elocution is, of course, concerned primarily with the clear articulation of sounds, rather than with the production of particular 'correct' sounds, but it is not surprising that once the notion of correct sounds develops it becomes linked inextricably to elocution. In the 1890s in Australia, elocution comes to include not just articulation of sounds but the production of correct sounds - or, as the commentators describe them, 'pure' sounds. This is not, however, the purity of Dixon, Bennett and Froude - where purity was the excision of dialectal features. Purity is now an ideal pronunciation, against which the bastard breeds can be judged.

Typical of the new emphasis is the appendix to the Victorian inspectors' reports for 1890-91 by George Lupton, a lecturer in elocution. It summarises his conclusions for the year after giving elocution classes in Ballarat, Geelong, Castlemaine and Melbourne: 'During the past year, attention has been given to the study of expression in reading, also to the purity of vowel pronunciation in 
vocality.' ${ }^{54}$ The 1892-93 Victorian report stresses that the 'purity of the vowel sounds' needs attention. ${ }^{55}$ The $1893-94$ Queensland report said that 'the most common faults were imperfect articulation of consonants, impure vowel sounds, and lack of voice'. ${ }^{56}$ The 1898 Prospectus for Wesley College in Melbourne reported that the headmaster, Thomas Palmer, had introduced elocution lessons for the boys in order to maintain 'above all purity of vowel sounds'.$^{57}$ A 1901-02 Victorian report asserts that there is 'much to be done' to achieve 'the production of pure vowel sounds'. 58

This emphasis on the purity of vowels and diphthongs continued with the introduction of phonics in the first decade of the twentieth century (the Oxford English Dictionary's first citation for this method of teaching reading is 1901). The teaching of phonics in NSW was being recommended by 1908 in the educational journals: 'Phonic exercises are necessary when the vocal organs are supple and adjustable, when the child is largely dominated by the influence of imitation. It should be possible to modify, if not eradicate, our so-called "Colonial twang". .59

A 1909 issue of the Public Instruction Gazette provides teachers with phonics exercises to use in classes. ${ }^{60}$ In 1916, the Education Gazette provided evidence that the teaching of the correct pronunciation of vowels had become part of the Revised Syllabus. ${ }^{61}$ A series of articles in the Gazette by Hyacinth M. Symonds explains how students can be taught the correct pronunciations of the vowels and diphthongs in the words go, day, try, cat, eat, school and cow, including information about correct lip and tongue positions. ${ }^{62}$ In Victoria, the new courses in phonics seem to have had the desired effect. The 1911-12 report states: 'The short daily drills in phonics are certainly having a good effect on the speech of our scholars: vowel sounds are becoming purer. ${ }^{63}$ The $1912-13$ report states: 'The effect of the training given to teachers by the instructors in elocution is markedly good, especially in the matter of clearer and more correct utterance. The vowel sounds are purer; the enunciation is more careful. ${ }^{64}$

This material has important consequences for our understanding of the history of the Australian accent. The scholarly study of Australian vowels and diphthongs begins with Mitchell ${ }^{65}$ and is cemented by Mitchell and Delbridge ${ }^{66}$ and Bernard. ${ }^{67}$ More recent studies by Harrington et al., ${ }^{68} \operatorname{Cox}^{69}$ and Cox and Palethorpe $^{70}$ have noted some slight shifts since the 1960s, but these shifts are not sufficiently significant to alter perceptions of those sounds that are most distinctive in Australian English. In 1946, Mitchell proposed a distinction between 'educated Australian' and 'broad Australian', ${ }^{71}$ but after their detailed studies of the speech of secondary students from across Australia in the early 1960s, Mitchell and Delbridge proposed three varieties, which they called broad Australian (spoken by 34 per cent of the population), general Australian (55 per cent) and cultivated Australian ( 11 per cent). ${ }^{72}$ There is no evidence for the 
existence of the cultivated variety in the nineteenth century, but we are now in a better position to understand what generated it: it was the product of the desire to move towards received pronunciation.

There is little evidence for the existence of broad Australian in the nineteenth century either. Research by Felicity Cox and Sallyanne Palethorpe on recordings of 12 rural men and women from central-western NSW and Tasmania, who were born in the 1880s, is revealing some surprising results. The researchers were expecting to find evidence of broad accents, since broad Australian was associated especially with rural areas, but the speakers had general Australian accents. ${ }^{73}$ Is it possible that broad Australian is a later development, just as cultivated Australian clearly is?

Central to the argument of this essay has been the fact that the noting of the quality of the vowels and diphthongs does not represent a shift in vowel or diphthong quality, but rather a shift in perceptions. G. L. James claimed he heard the make/mike shift in Sydney among "particularly the young girls, especially of the lower classes', and Justice Madden described the diphthongs of the 'average Australian youth'. One might be tempted to interpret this as evidence of a broadening among the youth, but the school evidence - in one case going back to 1860 - shows that what is new is not the phenomenon itself, but the noting of it. Cox suggests that broad Australian 'could have started in the First World War, and could be something to do with the diggers'.

World War I was certainly important in generating many new Australian words, ${ }^{74}$ the colloquial language of ordinary Australians was published in the numerous newspapers and magazines of the soldiers, and part of the diggers' sense of Australian identity was the awareness of how different their accent was to those of the British soldiers. I think broad Australian needs, however, to be seen in a wider context. Just as cultivated Australian is the product of the influence of Britishness and empire - among the 'imperial symbols' of Wellings' argument - so broad Australian becomes associated with 'the vernacular culture of the Australian people'. In the first half of the twentieth century, cultivated and broad Australian sit as extremes on either side of general Australian. The extremes have their cultural manifestations: cultivated Australian quintessentially on the ABC until the mid 1960s, broad Australian in a tradition that begins with the works of C. J. Dennis (thousands of copies of the 'trench' edition of Songs of the Sentimental Bloke were distributed to the troops in World War I) and climaxes even as a parody of itself in Afferbeck Lauder's Let Stalk Strine (1965) and Barry McKenzie.

By the 1970s, attitudes towards Australian English had changed radically. In 1976, there appeared the first general Australian dictionary, edited in Australia and representing the Australian language. This was Graeme Johnston's Australian Pocket Oxford Dictionary. The Macquarie Dictionary appeared in 1981. In 1987, 
the government report National Policy on Languages stated: 'Australian English is a dynamic but vital expression of the distinctiveness of Australian culture and an element of national identity. ${ }^{75}$ In 1988, there appeared The Australian National Dictionary: A Dictionary of Australianisms on Historical Principles, edited by W. S. Ramson. In 1992, at a conference on the languages of Australia, David Blair argued: 'Australian English is currently a self-confident dialect, reasonably secure in itself, and prepared to set its own standards. It is confident enough to be open to outside cultural influences, as is the society in which it functions. $^{\text {} 76}$ Australian English was finally naturalised-and, as if as a consequence of this naturalisation, the two extremes, cultivated and broad Australian, were on the decline.

Since the 1970s, cultivated Australian has lost its former status, and such an accent is more likely to be a hindrance than an advantage in contemporary Australia. Broad Australian is rarely heard, except when consciously 'cultivated' for its advertising or iconising functions - perhaps a reflection of the changing demographics of Australian society, perhaps an admission that its opposing partner, cultivated, is now devoid of power. The wheel has turned full circle. Most Australians now speak general Australian, or, more accurately, Australian - something very similar to the foundation accent of the 1820s.

\section{ENDNOTES}

1 Board, Ruby W. 1927, Australian Pronunciation: A Handbook for the Teaching of English in Australia, Government Printer, Sydney, p. 6.

2 Ellis, A. J. 1869, On Early English Pronunciation, vol. 1, Trübner, London, p. 23.

3 Wellings, Ben 2005, 'Crown and Country: empire and nation in Australian nationalism, 1788-1999', Journal of Australian Colonial History, 5 (2005), pp. 148-70 at p. 170.

4 Mallarky, Edith M. 1914, 'Some Means of Training in Speech and other Papers', Records of the Education Society, Government Printer, Sydney, p. 8.

5 Desmond, Valerie 1911, The Awful Australian, J. Andrews \& Co., Sydney, p. 21.

6 Churchill, William 1911, Beach-la-mar, the jargon or trade speech of the western Pacific, Carnegie Institute of Washington, Washington D.C., p. 14.

7 Cited in Mitchell, A. G. 1946, The Pronunciation of English in Australia, Angus \& Robertson, Sydney, p. 63.

8 Cunningham, Peter 1827, Two Years in New South Wales, vol. 2, H. Colburn, London, p. 60.

9 Meredith, Mrs Charles 1844, Notes and Sketches of New South Wales During a Residence in the Colony from 1839 to 1844, John Murray, London, p. 50.

10 Horne, R. H. 1859, Australian facts and prospects: to which is prefixed the author's Australian autobiography, Smith, Elder, London, refers to the 'nasal twang' (p. 67).

11 Boldrewood, Rolf 1979, Robbery Under Arms, A. Brissenden (ed.), University of Queensland Press, St Lucia, p. 310. The novel was first published in serial form in 1882-83.

12 Praed, Rosa 1889, The Romance of a Station: An Australian Story, Chatto \& Windus, London, p. 22.

13 Praed, Rosa 1893, Outlaw and Lawmaker, Chatto \& Windus, London, p. 20.

14 Mitchell, The Pronunciation of English in Australia, pp. 5-10, dismisses most of the stereotypes.

15 Dixon, James 1822, Narrative of a Voyage to New South Wales and Van Dieman's Land in the Ship 'Skelton' during the year 1820, John Anderson, Edinburgh, p. 46.

16 See Maclagan, Margaret A. and Elizabeth Gordon 2004, 'The Story of New Zealand English: What the ONZE Project Tells Us', Australian Journal of Linguistics, vol. 24, no. 1, pp. 41-56; Trudgill, Peter 
2004, New-dialect formation: the inevitability of colonial Englishes, Edinburgh University Press, Edinburgh. For a survey of earlier theories about the development of the Australian accent, see Cochrane, G. R. 1989, 'Origins and Development of the Australian Accent', in Peter Collins and David Blair (eds), Australian English: the language of a new society, University of Queensland Press, St Lucia, pp. 176-86.

17 Bennett, George 1834, Wanderings in New South Wales, Batavia, Pedir Coast Singapore, and China; being the journal of a naturalist in those countries during 1832, 1833, and 1834, vol. 1, R. Bentley, London, p. 331 .

18 Leakey, Caroline 1859, The Broad Arrow, Richard Bentley, London, pp. 96-7.

19 Froude, James 1886, Oceana, or, England and her colonies, Charles Scribner's Sons, New York, p. 84.

20 'Report from School Commissioners on State of Education, 1855', Journal of the Legislative Council of New South Wales, Session 1856-57, vol. 1, p. 269.

21 'National Education Report, 1863', Journal of the Legislative Council of New South Wales, Session 1864, vol. 11, p. 90.

22 'Report of the Minister of Public Instruction for 1875-76', Victorian Parliamentary Papers, Session 1876 , vol. 3, no. 46 , p. 57.

23 'Report of the Minister of Public Instruction for 1893-94', Victorian Parliamentary Papers, Session 1877-78, vol. 2, no. 47, p. 44.

24 'Report of the Minister of Public Instruction for 1879-80', Victorian Parliamentary Papers, Session 1880-81, vol. 3, no. 31, p. 190.

25 'Report of the Minister of Public Instruction for 1884-85', Victorian Parliamentary Papers, Session 1885, vol. 4, no. 74, p. 134.

26 'Report of the Secretary for Public Instruction for 1886', Votes and Proceedings of the Legislative Assembly, Queensland, Session 1887, vol. 3, p. 488.

27 'National Education Report for 1861', Journal of the Legislative Council of New South Wales, Session 1862, vol. 9, part 1, p. 334.

28 'Board of Education Report for 1869', Journals of the House of Assembly, Tasmania, Session 1870, vol. 19 , no. 18 , p. 17.

29 'Report of the Minister of Public Instruction for 1891-92', Victorian Parliamentary Papers, Session 1892-93, vol. 5, no. 133, p. 43.

30 'Report of the Minister of Public Instruction for 1891-92', Victorian Parliamentary Papers, Session 1892-93, vol. 5, no. 133, p. 80.

31 'Report of the Minister of Public Instruction for 1891-92', Victorian Parliamentary Papers, Session 1892-93, vol. 5, no. 133, p. 43.

32 'Report of the Minister of Public Instruction for 1893-94', Victorian Parliamentary Papers, Session 1894-95, vol. 2, no. 3, p. 41.

33 Report in the New South Wales Educational Gazette, 1 August 1893, p. 45.

34 'Report of the Minister of Public Instruction for 1885-86', Victorian Parliamentary Papers, Session 1886, vol. 3, no. 89, p. 153.

35 'Report of the Minister of Public Instruction for 1885-86', Victorian Parliamentary Papers, Session 1886, vol. 3, no. 89, p. 153.

36 'Report of the Minister of Public Instruction for 1891-92', Victorian Parliamentary Papers, Session 1892-93, vol. 5, no. 133, p. 43.

37 Report in the New South Wales Educational Gazette, 1 August 1893, p. 45.

38 'Report of the Minister of Public Instruction for 1893-94', Victorian Parliamentary Papers, Session 1894-95, vol. 2, no. 3, p. 41.

39 'Report of the Minister of Public Instruction for 1899-1900', Victorian Parliamentary Papers, Session 1900 , vol. 2, no. 17, p. 61 .

40 'Report of the Minister of Public Instruction for 1899-1900', Victorian Parliamentary Papers, Session 1900 , vol. 2, no. 17, p. 61 .

41 'Report of the Minister of Public Instruction for 1902-03', Victorian Parliamentary Papers, Session 1904, vol. 2, no. 1, pp. 35, 52.

42 'Report of the Minister of Public Instruction for 1903-04', Victorian Parliamentary Papers, Session 1905, vol. 3, no. 1, p. 37. 
43 'Report of the Minister of Public Instruction for 1906-07', Victorian Parliamentary Papers, Session 1908, vol. 1, no. 2, p. 35.

44 'Report of the Minister of Public Instruction for 1908-09', Victorian Parliamentary Papers, Session 1910, vol. 2, no. 5, p. 33

45 'Report of the Director of Education for 1910', Journals of the House of Assembly, Tasmania, Session 1911 , vol. 65 , no. 9, p. 11

46 'Report of the Minister of Public Instruction for 1911-12', Victorian Parliamentary Papers, Session 1913-14, vol. 2, no. 6, p. 57.

47 Cited from a reprinting of a newspaper article by McBurney in the Press (New Zealand), 5 October 1887, in Turner, G. W. 1967, 'Samuel McBurney's Newspaper Article on Colonial Pronunciation', AUMLA, 27, pp. 82-3.

48 James, G. L. 1892, Shall I Try Australia?, L. Upcott Gill, London, p. 253.

49 Argus (Melbourne), 21 December 1893, p. 4.

50 Cited from Honey, John 1989, Does Accent Matter? The Pygmalion Factor, Faber \& Faber, London, p. 23.

51 Mugglestone, Lynda 2003, Talking Proper: the rise of accent as social symbol, Second edition, Oxford University Press, Oxford, esp. pp. 79-80.

52 Honey, Does Accent Matter?, pp. 12-27; also Honey, John 1997, Language is Power: The Story of Standard English and its Enemies, Faber \& Faber, London, esp. pp. 101-4.

53 On elocution in Australia, see Damousi, Joy 2007, “"The Filthy American Twang": Elocution, the Advent of American "Talkies", and Australian Cultural Identity', American Historical Review, vol. 112, no. 2, pp. 394-416.

54 'Report of the Minister of Public Instruction for 1890-91', Victorian Parliamentary Papers, Session 1891, vol. 4, no. 73, p. 118.

55 'Report of the Minister of Public Instruction for 1892-93', Victorian Parliamentary Papers, Session 1893, vol. 2, no. 41, p. 53.

56 'Report of the Secretary for Public Instruction for 1894', Votes and Proceedings of the Legislative Assembly, Queensland, Session 1895, vol. 2, p. 954.

57 Reported in Crotty, Martin 2001, Making the Australian Male: Middle-class Masculinity 1870-1920, Melbourne University Press, Melbourne, p. 38.

58 'Report of the Minister of Public Instruction for 1901-02', Victorian Parliamentary Papers, Session 1902-03, vol. 2, no. 28, p. 78.

59 Public Instruction Gazette: The Official Gazette of the Public Instruction Department of New South Wales, 30 April 1908, p. 297.

60 Public Instruction Gazette: The Official Gazette of the Public Instruction Department of New South Wales, 30 September 1909, pp. 308-17.

61 The Education Gazette: Official Gazette of the Education Department of New South Wales, 1 April 1916 , p. 80.

62 Ibid., pp. 79-80.

63 'Report of the Minister of Public Instruction for 1911-12', Victorian Parliamentary Papers, Session 1913-14, vol. 2, no. 6, p. 62.

64 'Report of the Minister of Public Instruction for 1912-13', Victorian Parliamentary Papers, Session 1914, vol. 2, no. 1, p. 60.

65 Mitchell, A. G. 1946, The Pronunciation of English in Australia, Angus \& Robertson, Sydney.

66 Mitchell, A. G. and Arthur Delbridge 1965, The Pronunciation of English in Australia, Revised edition, Angus \& Robertson, Sydney; Mitchell, A. G. and Arthur Delbridge 1965, The Speech of Australian Adolescents, Angus \& Robertson, Sydney.

67 Bernard, J. 1967, Some measurement of some sounds of Australian English, Ph.D. Dissertation, University of Sydney; 'Toward the acoustic specification of Australian English', Zeitschrift fürPhonetik, vol. 2, no. 3, 1970, pp. 113-28.

68 Harrington, Jonathan, Felicity Cox and Zoe Evans 1997, 'An acoustic phonetic study of broad, general, and cultivated Australian English vowels', Australian Journal of Linguistics, vol. 17, no. 2, pp. 155-84. 
69 Cox, Felicity 1998, 'The Bernard data revisited', Australian Journal of Linguistics, vol. 18, no. 1, pp. 29-55.

70 Cox, Felicity and Sallyanne Palethorpe 2000, 'Vowel change: synchronic and diachronic evidence', in David Blair and Peter Collins (eds), English in Australia, John Benjamins, Amsterdam, pp. 17-44.

71 Mitchell 1946, The Pronunciation of English in Australia, pp. 11-18.

72 Mitchell and Delbridge 1965, The Pronunciation of English in Australia, pp. 11-19.

73 Reported in 'Rack off Hoges, we just don't like the way you speak', Sydney Morning Herald, 25 January 2005, p. 1.

74 See Laugesen, Amanda 2005, Diggerspeak: The Language of Australians at War, Oxford University Press, Melbourne.

75 Lo Bianco, J. 1987, National Policy on Languages, Australian Government Publishing Service, Canberra, p. 72 .

76 Blair, David 1993, 'Australian English and Australian identity', in Gerhard Schulz (ed.), The Languages of Australia, Australian Academy of the Humanities, Canberra, p. 70. 